\title{
Penerapan Teknik Makrame Sebagai Elemen Dekoratif Pada Produk Muslim Fesyen
}

\author{
Amalia Syahputri Pakpahan dan Citra Puspitasari \\ Program Studi S1 Kriya, Fakultas Industri Kreatif, Universitas Telkom, Bandung, Indonesia \\ e-mail: amalia.pakpahan@yahoo.com/citrapuspitasari@telkomuniversity.ac.id
}

\begin{abstract}
Abstrak-Makrame sebagai salah satu teknik rekarakit memiliki potensi daya cipta yang tak terhingga. Simpulan dasar makrame dapat divariasi dan dikombinasikan dalam penggayaan konsep sehingga menghasilkan elemen dekoratif yang eksploratif. Dewasa ini, telah terjadi peningkatan konsumsi muslim fesyen yang mengakibatkan majunya perkembangan eksplorasi dalam dekorasi muslim fesyen, namun penggunaan rekarakit khususnya makrame masih terbatas dan penerapannya hanya pada pola dasar. Maka diperlukanlah pengembangan elemen dekoratif makrame pada produk busana muslim. Metode yang digunakan adalah studi literatur, observasi dan eksperimen. Adapun output dalam perancangan yang dilakukan adalah alternatif desain busana pesta muslim memanfaatkan elemen dekoratif makrame.
\end{abstract}

Kata Kunci-makrame, elemen dekoratif, muslim fesyen

Abstract-Macrame as one of the structure designs technique has unlimited creative potential. Basic knots of macrame can be varied and combined in the styling of concepts so as to produce decorative elements that are exploratory. Nowadays, there has been an increase in consumption of Muslim fashion which has led to the rapid development of exploration in the decoration of Muslim fashion, but the use of macrames is still limited and its application is only on the basic pattern. Therefore the development of macrame as decorative elements is needed in Muslim fashion. The method used is literature study, observation and experiments. The output in the design carried out is an alternative to Muslim fashion design utilizing macrame decorative elements.

Keywords—macrame, decorative element, fashion muslim

\section{PENDAHULUAN}

Industri fesyen muslim di Indonesia kian mengalami perkembangan yang signifikan. Industri yang terus meningkat tujuh persen setiap tahunnya. Berdasarkan 750 ribu IKM yang ada di Indonesia, 30 persen disumbang oleh industri fesyen muslim [1]. Dewasa ini, fesyen muslim terus mengalami transformasi dari gaya konservatif menjadi lebih kekinian, yang mana salah satunya disebabkan oleh keterbukaan pola pikir masyarakat muslimah yang memengaruhi pemilihan produk yang rasional dan melek terhadap ajaran Islam [2]. Selain itu, selebriti muslimah dan desainer fesyen muslim Indonesia turut berperan dalam peningkatan minat masyarakat untuk menggunakan produk yang fashionable. Akibat dari pertumbuhan pada sektor fesyen muslim di Indonesia ini, terbentuk potensi untuk menawarkan alternatif desain elemen dekoratif busana yang eksploratif [3]. Dekorasi pada busana menjadikan mode busana berkembang lebih dinamis, mengingat siluet atau desain bentuk dasar busana secara umum tidak seketika berubah, tetapi berevolusi secara bertahap dari satu ke yang lain melalui perubahan detail [4]. Elemen dekoratif yang berfungsi untuk meningkatkan kualitas dan daya tarik suatu produk dapat dikembangkan dengan teknik rekarakit, khususnya makrame. Hal tersebut didasarkan atas simpulan dasar makrame yang dapat dikombinasikan dan dimodifikasikan sehingga menciptakan variasi simpul yang tak terbatas pengembangannya [5].

Makrame dalam pengertiannya sebagai hasil kerajinan kriya tekstil dengan teknik simpul yang menggunakan tali atau benang, terlihat mengintimidasi dan rumit, namun sebenarnya hanya terdiri dari dua simpulan dasar, simpul tunggal dan simpul gordin [6]. Keterbatasan penerapan makrame pada busana muslim menjadikannya peluang dalam pengembangannya. Maka dari itu, perlu kebaruan yang menawarkan penerapan teknik makrame sebagai elemen dekoratif yang lebih eksploratif dengan memanfaatkan penggayaan konsep pada produk fesyen muslim.

\section{A. Rumusan Masalah}

Berikut adalah kesenjangan yang melatarbelakangi dilakukannya penelitian, yaitu :

1. Keterbatasan penerapan teknik makrame pada produk fesyen muslim.

2. Elemen dekoratif yang memanfaatkan makrame masih minim eksploratif dan terbatas pada pola simpulan dasar.

B. Batasan Masalah

1. Penggunaan teknik makrame sebagai teknik yang akan diterapkan dalam produk busana muslim.

2. Pengembangan desain elemen dekoratif makrame dalam penggayaan konsep.

C. Tujuan Penelitian

Adapun yang menjadi tujuan penelitian ini yaitu:

1. Terciptanya pengembangan teknik makrame yang berpotensi diterapkan dalam busana pesta muslim.

2. Terciptanya alternatif desain elemen dekoratif makrame dengan konsep konten lokal Anggrek Pensil.

\section{METODE}

Metodologi penelitian yang dilakukan adalah metodologi penelitian kualitatif, dengan data penelitian diperoleh dari hal - hal yang diamati, didengar, dirasa dan dipikirkan 


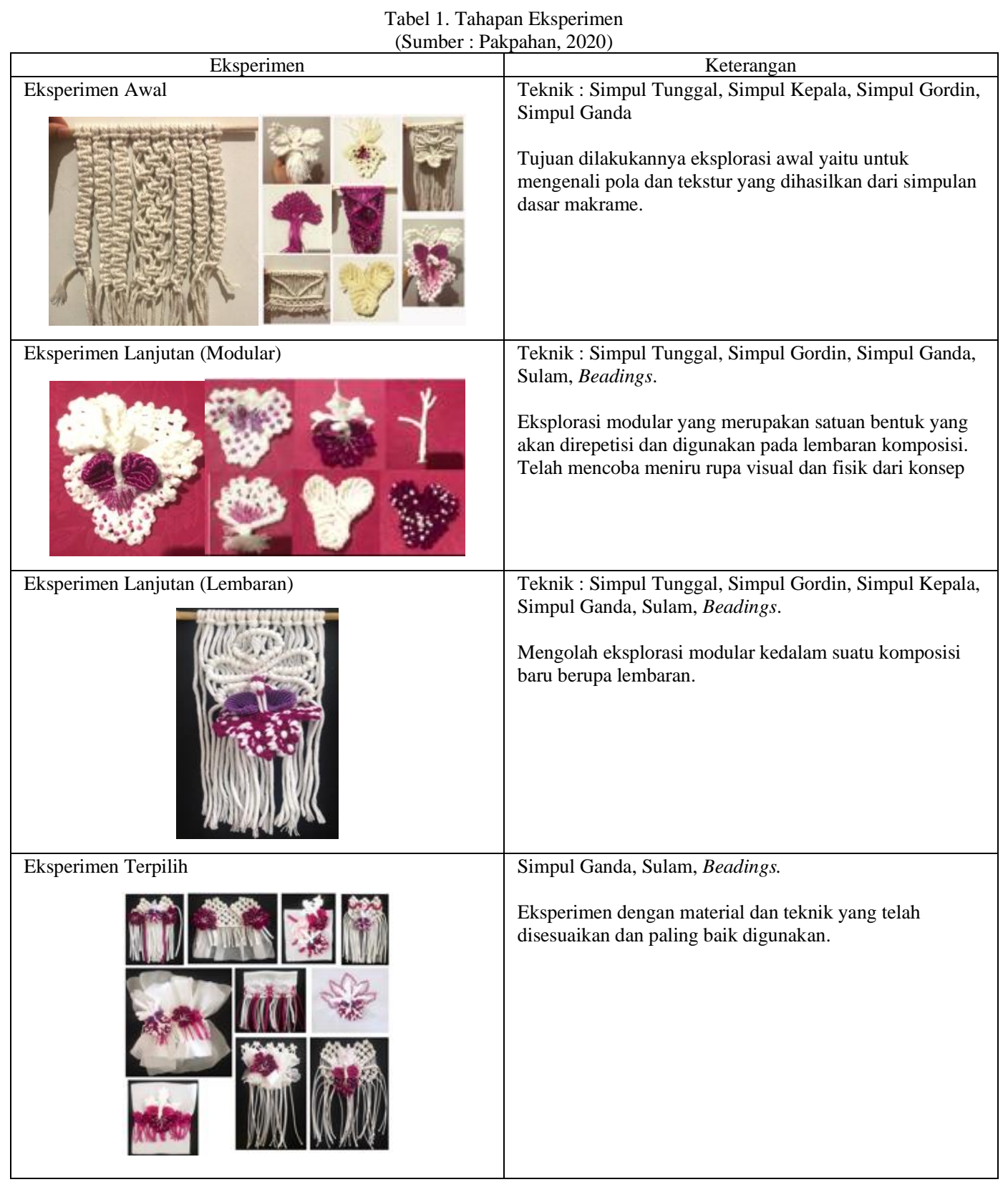

peneliti yang berkaitan dengan fokus peneliti [7]. Berikut pemaparan metode pengumpulan data yang dilakukan :

\section{A. Studi Literatur}

Studi literatur dilakukan melalui buku, jurnal, karya ilmiah, internet dan media lainnya yang dapat membantu penelitian. Kajian pustaka diperoleh dari beberapa literatur yang membahas tentang makrame, teknik yang dihasilkan, perkembangan fesyen muslim, dan penerapan teknik makrame dalam produk busana muslim. Adapun dilakukan juga analisis dalam literatur mengenai elemen dekoratif. Hal ini bertujuan mana topik ini berkembang. untuk memperkuat dasar penelitian dan mengetahui sejauh

\section{B. Observasi}

Observasi dilakukan dengan cara pengamatan disertai analisis karakteristik dan referensi busana artis muslimah yang kerap digunakan pada beberapa kesempatan melalui sosial media dan internet. Kemudian melakukan observasi penerapan teknik makrame pada busana muslim, seperti contoh pada Gambar 1, busana karya Rosie Rahmadi yang menggunakan teknik simpul ganda makrame pada koleksi Graduation Show IFI 2018. Selain itu, dilakukan juga kajian lapangan terhadap beberapa brand busana muslimah yang berlokasi di Bandung seperti IM\&Co., HijUp, Anggia Handmade, Irna La Perle, dll. yang bertujuan untuk mengetahui tren pasar busana muslim yang sedang diminati saat ini. Metode ini juga dilakukan dilandaskan untuk mengetahui hal-hal yang berpotensi untuk diangkat. Berdasarkan observasi yang telah dilakukan didapatkan fakta bahwasanya penerapan teknik rekarakit khususnya makrame sangat terbatas apabila dibandingkan dengan teknik rekalatar seperti bordir, print dan embellishment.

\section{Eksperimen}

Eksperimen dilakukan dalam sejumlah ragam tahapan, dimulai dari pembuatan eksplorasi teknik dasar, modul dan pengembangan komposisi pada lembaran yang dituangkan dalam Tabel 1. 


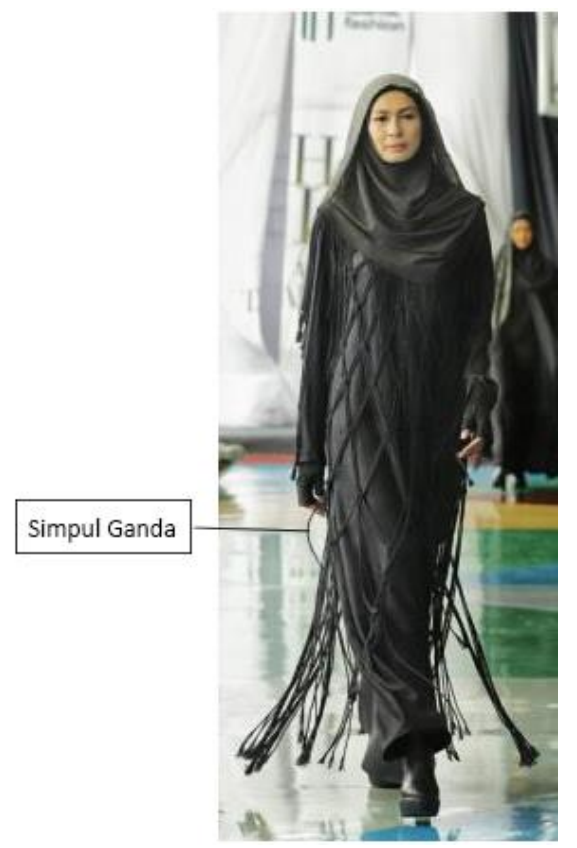

Gambar 1. Penerapan Makrame Pada Busana Muslim (Sumber : Firda, 2018)

\section{HASIL DAN PEMBAHASAN}

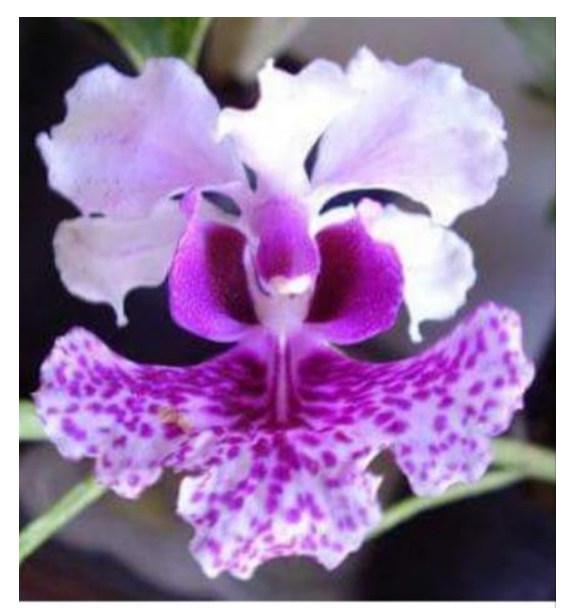

Gambar 2. Bunga Anggrek Pensil

(Sumber : Titan Mart, 2019)

Berdasarkan data yang telah diperoleh, dapat diketahui bahwa penerapan teknik rekarakit terutama makrame pada produk fesyen muslim sangatlah minim. Adapun jika ditemukan, penggunan teknik ini terbatas pada pola simpulan dasar tanpa modifikasi eksploratif [8]. Teknik rekalatar seperti bordir dan print lebih kerap ditemukan. Maka dari itu, perlu adanya kebaruan yang menawarkan alternatif inovasi elemen dekoratif makrame pada produk busana muslim populer. Setelah mengidentifikasi tren busana muslim yang lebih didominasi oleh rekalatar dengan cara menganalisis hasil kajian pustaka maupun kajian lapangan, selanjutnya adalah mengkomparasikan desain yang sudah ada dengan batasan yang telah ditentukan. Kemudian menghasilkan ide atau gagasan konsep untuk mengetahui cara serta karya yang dapat dibuat menggunakan teknik makrame untuk dijadikan elemen dekoratif sebuah busana.

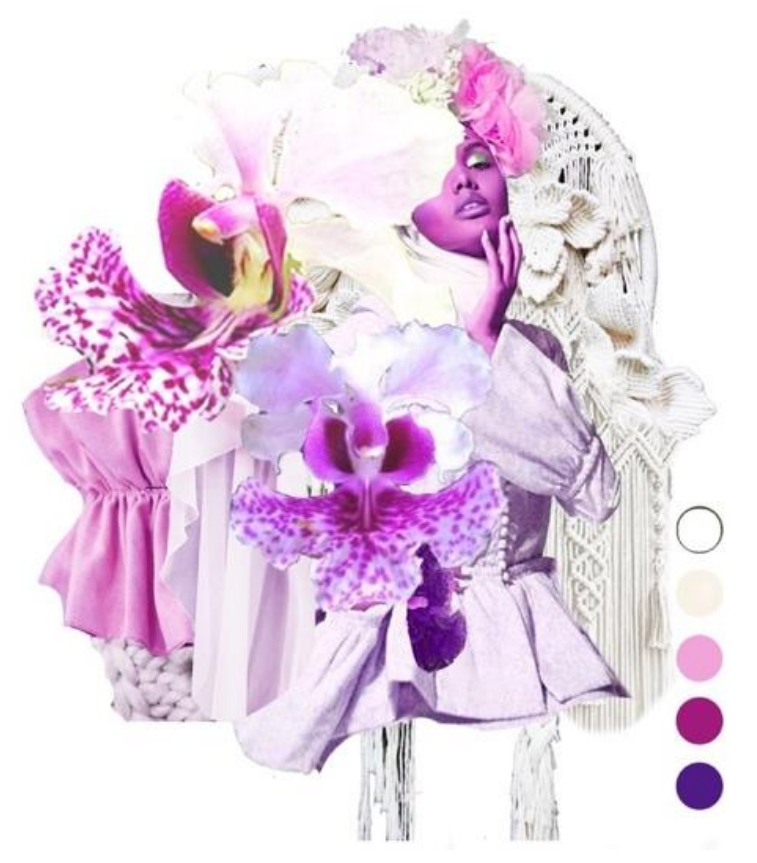

Gambar 3. Moodboard (Sumber : Pakpahan, 2020)

\section{A. KONSEP DESAIN}

Setelah mengkaji hasil pengolahan data lapangan, pustaka, dan eksperimen dalam penelitian ini, kemudian dituang dalam konsep yang akan diusung, yang mana mengangkat inspirasi sebuah flora endemik Indonesia yaitu Anggrek Pensil yang ditunjukkan dalam Gambar 2. Pengangkatan flora tersebut didasarkan atas penobatan gelar Ratu Anggrek dan penghargaan First Class Certificate pada Tahun 1882 yang diberikan oleh Kerajaan Inggris [9]. Konsep Ratu dari gelar Ratu Anggrek tersebut yang kemudian menjadi pedoman dalam perancangan konsep desain ini. Konsep perancangan elemen dekorasi mengambil karakteristik pola simpulan makrame dan rupa visual fisik Anggrek Pensil sebagai inspirasi. Pola makrame yang kemudian dieksplorasi sedemikian rupa melewati tahapan proses mengejar inspirasi untuk menciptakan variasi baru yang sesuai digunakan dalam busana pesta muslim, yang merupakan sebuah busana yang dipakai untuk menghadiri suatu kesempatan acara formal [10]. Bunga Anggrek Pensil sendiri terdiri dari bunga besar bergaris dengan tiga helai kelopak atas yang memiliki urat halus bewarna lebih gelap yang cenderung bercak ungu, memiliki daun kelopak samping yang bewarna putih dan terdapat buah pada bagian tengah bunga yang umumnya berbentuk bulat memanjang yang meruncing. Adapun pinggirannya bersegi dengan panjang $6-5 \mathrm{~cm}$ dengan garis tengah $2 \mathrm{~cm}$. Pertimbangan dalam pemilihan warna menyesuaikan kembali kepada Anggrek Pensil dan karakteristik target market yang merupakan artis atau wanita yang memiliki kebutuhan dalam busana pesta muslim. Berdasarkan moodboard, dapat dilihat pada Gambar 3, nuansa warna Anggrek Pensil adalah ungu yang secara psikologi warna melambangkan sifat kemewahan dan pangkat merupakan kelompok warna feminin [11] mendukung penobatan Anggrek Pensil sebagai Ratu Anggrek. Sehingga konsep perancangan tertuju untuk membuat desain yang memiliki kesan elegan. 


\section{B. ANALISIS EKSPERIMEN}

Setelah mencermati sifat simpulan dasar makrame, kemudian diolah dengan menyesuaikan bentuk rupa dari inspirasi.

Tabel 2. Penerapan Simpul Dasar Sumber : Pakpahan, 2020

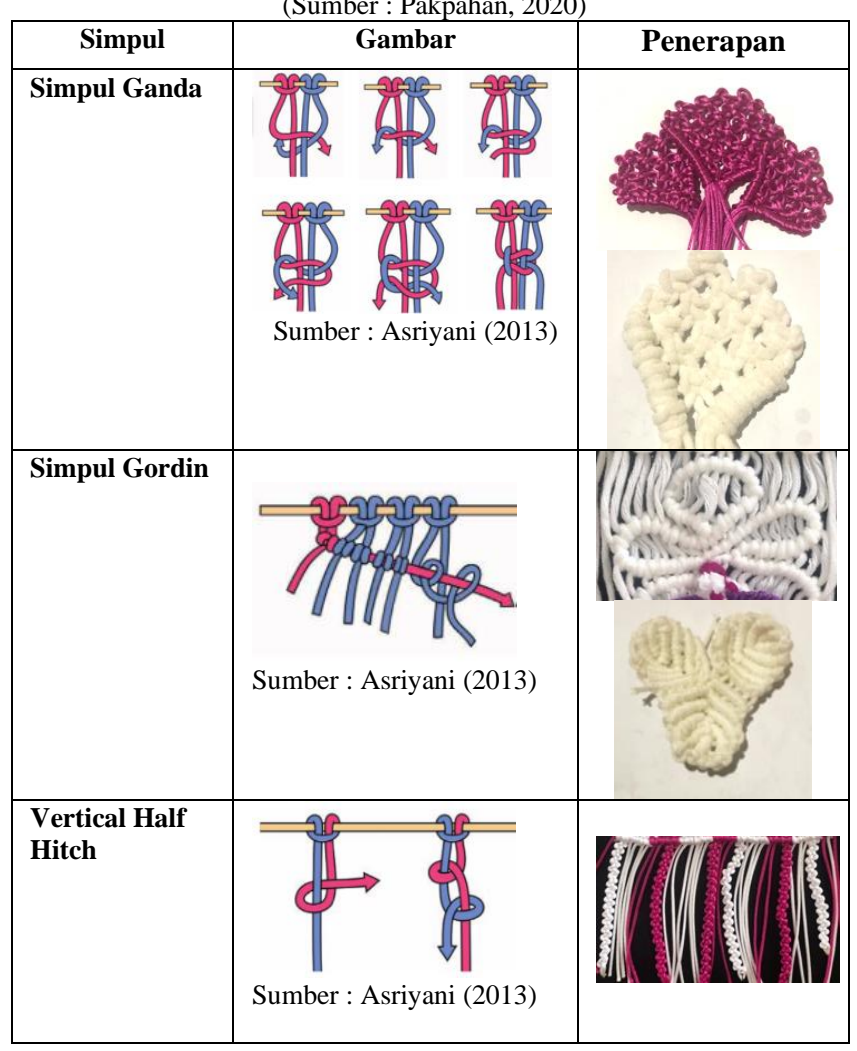

Tabel 2 menunjukkan penerapan simpul-simpul dasar, dimana simpul dasar ganda yang tercipta dari penggabungan dua arah simpul tunggal dapat menghasilkan bentuk dengan beragam kelebaran, berfungsi untuk membuat modul mahkota atau kelopak bunga. Kemudian simpul gordin menghasilkan garis yang berguna untuk finishing tepian dan membuat outline, apabila penerapannya direpetisi pun mampu menciptakan kelopak cekung. Terakhir, simpul dasar yang merupakan peranakan dari simpul gordin yaitu vertikal half hitch berfungsi untuk menciptakan tali, baik untuk rumbai yang menjuntai atau untuk merepresentasikan bentuk batang tumbuhan bunga Anggrek Pensil.

Dari hasil rangkaian eksperimen yang dilakukan, lahir fakta bahwa pengkombinasian dari beberapa simpulan dasar makrame dapat menghasilkan variasi bentuk baru. Penggabungan simpul gordin dan simpul ganda dapat menghasilkan bentuk kelopak dan bunga utuh Anggrek Pensil. Adapun sifat dasar dari struktur makrame menghasilkan untaian benang yang dapat dijadikan sebagai aksen rumbai pada elemen dekorasi.

Berdasarkan Gambar 4, eksperimen modular yang merupakan satuan bentuk yang kemudian dikomposisikan pada lembaran adalah pengembangan dari variasi pola menggunakan simpul dasar ganda dan gordin yang menghasilkan bentuk bagai kelopak bunga. Variasi pola tersebut yang kemudian dieksperimen lanjut dengan mengkombinasikan dua jenis variasi yang sama atau dengan variasi yang berbeda. Dikembangkan dengan bermacam material yang paling sesuai.

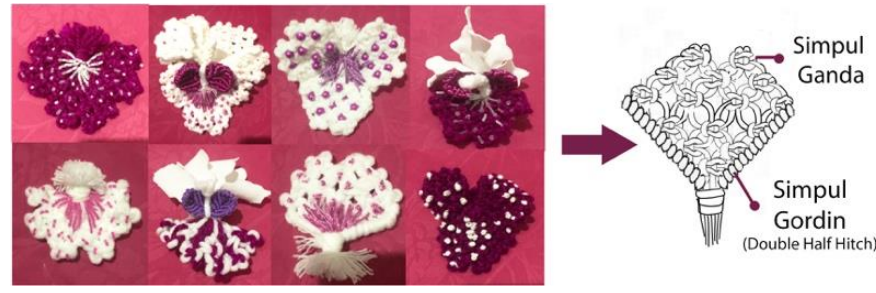

Gambar 4. Hasil Eksperimen Modular (Sumber : Pakpahan, 2020)

Tabel 3 berikut menjelaskan analisa penggunaan material yang diterapkan pada perancangan ini. ketiga material tersebut digunakan sesuai dengan keunggulannya. Eksperimen didorong juga dengan beragam material pendukung yang dapat mendorong rupa visual inspirasi. Beberapa material pendukung yang digunakan adalah mutemute, kain combed, dan kain organza. Mute-mute dapat merepresentasikan bercak pada kelopak, mendorong kesan mewah. Kemudian kain combed digunakan sebagai alternatif kelopak atas bunga Anggrek Pensil yang sangat melambai. Terakhir, kain organza yang merupakan repetisi irama kelopak, mendukung berdirinya eksplorasi dan sebagai pendorong hiasan renda.

Tabel 3. Analisa Material

(Sumber : Pakpahan, 2020)

\begin{tabular}{|l|l|l|}
\hline \multicolumn{1}{|c|}{ Material } & \multicolumn{1}{|c|}{ Keunggulan } & \multicolumn{1}{c|}{ Kekurangan } \\
\hline yarn & $\begin{array}{l}\text { Ringan dan menghasilkan } \\
\text { bentuk mahkota dan } \\
\text { kelopak bunga dengan } \\
\text { tekstur flare. }\end{array}$ & Cenderung berserabut. \\
\hline Tali satin & $\begin{array}{l}\text { Bahannya bersifat jatuh } \\
\text { sehingga cocok digunakan } \\
\text { sebagai rumbai. Memiliki } \\
\text { kerapatan dan } \\
\text { menghasilkan kesan } \\
\text { mengkilap. }\end{array}$ & $\begin{array}{l}\text { Apabila digunakan } \\
\text { sebagai bahan modular } \\
\text { kelopak berat dan } \\
\text { tidak melambai. }\end{array}$ \\
\hline $\begin{array}{l}\text { Benang } \\
\text { Polyester }\end{array}$ & $\begin{array}{l}\text { Rapat dan cocok } \\
\text { digunakan untuk membuat } \\
\text { column pada labellum } \\
\text { bunga (kelopak cekung) }\end{array}$ & $\begin{array}{l}\text { Ukurannya yang kecil } \\
\text { membuatnya } \\
\text { menghasilkan tekstur } \\
\text { rapat dan berat. } \\
\text { Sehingga harus } \\
\text { digunakan pada } \\
\text { bagian kaku. }\end{array}$ \\
\hline & \multicolumn{2}{|l}{} \\
\hline
\end{tabular}

Gambar 5 menunjukkan analisis hasil eksperimen terpilih yang akan digunakan pada desain akhir. Kesimpulan dari rangkaian eksperimen yang telah dilakukan adalah sebagai berikut :

1. Kombinasi simpul dasar ganda dan gordin dapat menciptakan variasi bentuk kelopak yang kemudian dapat direpetisi menghasilkan bentuk mahkota bunga.

2. Material benang yang jatuh namun tidak berserabut dan berserat lebih cocok digunakan dalam makrame, seperti yang digunakan dalam penelitian ini yaitu tali satin.

3. Modular makrame dapat digunakan sebagai satuan bentuk yang lepas dan tidak dibatasi peletakkannya.

4. Simpul variasi dapat digunakan sebagai landasan awal.

5. Makrame dapat berdiri sendiri sebagai lembaran, namun dapat juga dibantu dengan material pendukung yang bertujuan untuk memperindah makrame itu sendiri.

Untaian benang yang dihasilkan makrame dapat dijadikan rumbai atau fringe. 

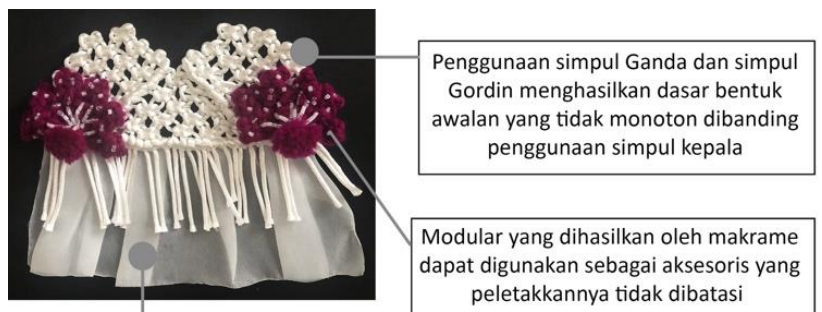

Makrame dapat dimanfaatkan juga sebagai bentuk renda, hasil untaian benang (fringe) mendukung kesan hiasan tepi.

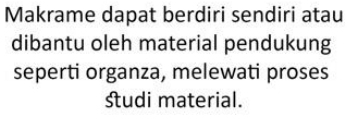
dibantu oleh material pendukun seperti organza, melewati proses studi material.

Modular yang dihasilkan oleh makrame dapat digunakan sebagai aksesoris yang peletakkannya tidak dibatasi

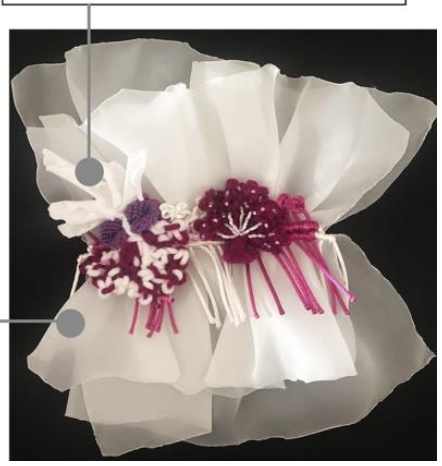

Gambar 5. Analisis Hasil Eksperimen (Sumber : Pakpahan, 2020)

\section{SKETSA DAN ANALISA}

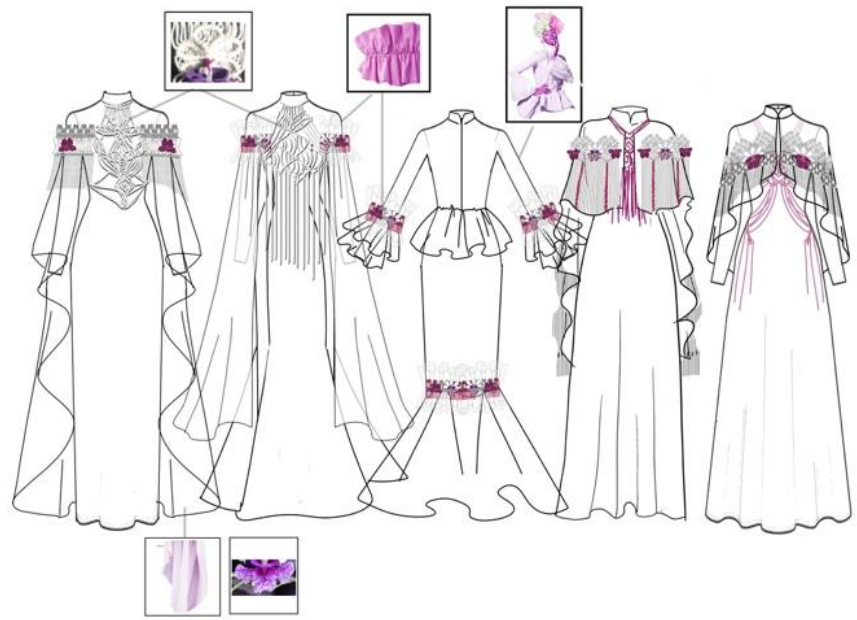

Gambar 6. Skema Sketsa

(Sumber : Pakpahan, 2020)

Sketsa busana yang dirancang dalam penelitian ini adalah busana muslim untuk kebutuhan pesta. Gambar 6 menujukkan skema sketsa desain yang telah dibuat :

Setelah memahami sifat dari rangkaian yang dihasilkan makrame, kemudian diadaptasikan kedalam suatu rancangan desain. Pertimbangan perancangan busana designer wear untuk kebutuhan pesta kembali kepada konsepnya yang selaras dengan moodboard, yang mana merupakan kategori busana untuk kesempatan formal yang mengedepankan estetika dan keterampilan. Teknik makrame yang merupakan teknik kerajinan simpul tali-temali membutuhkan keterampilan dan kreatifitas tinggi. Maka dari itu penerapan teknik tersebut dalam busana pesta muslim dirasa sesuai. Melihat pada Gambar 7 adalah model busana adalah dress dengan potongan standar yang memiliki elemen dekoratif makrame sebagai pusat perhatian. Sifat untaian yang dihasilkan rangkaian makrame dimanfaatkan layaknya rumbai dan renda. Kemudian modular bunga utuh dari makrame direpetisi dalam komposisi sehingga menciptakan padanan dekorasi yang tampak harmonis dan konsisten.

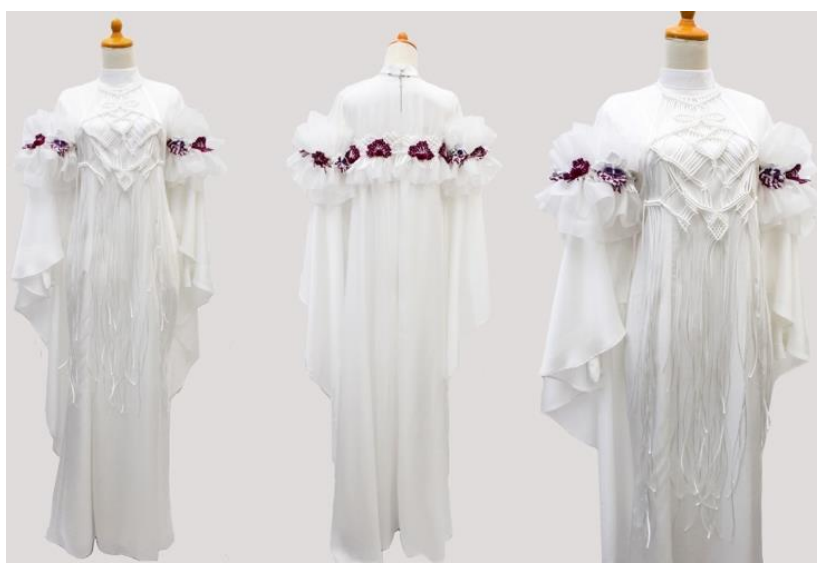

Gambar 7 Visualisasi Rancangan Desain (Sumber : Pakpahan, 2020)

Setelah mengeksekusi sketsa rancangan menjadi produk akhir, melewati proses pencarian bahan, penjahitan dan finishing maka produk akhir busana pesta muslim dapat divisualisasikan dan ditunjukkan dengan detail gambar eksplorasi yang digunakan ditunjukkan dalam Gambar 8 .

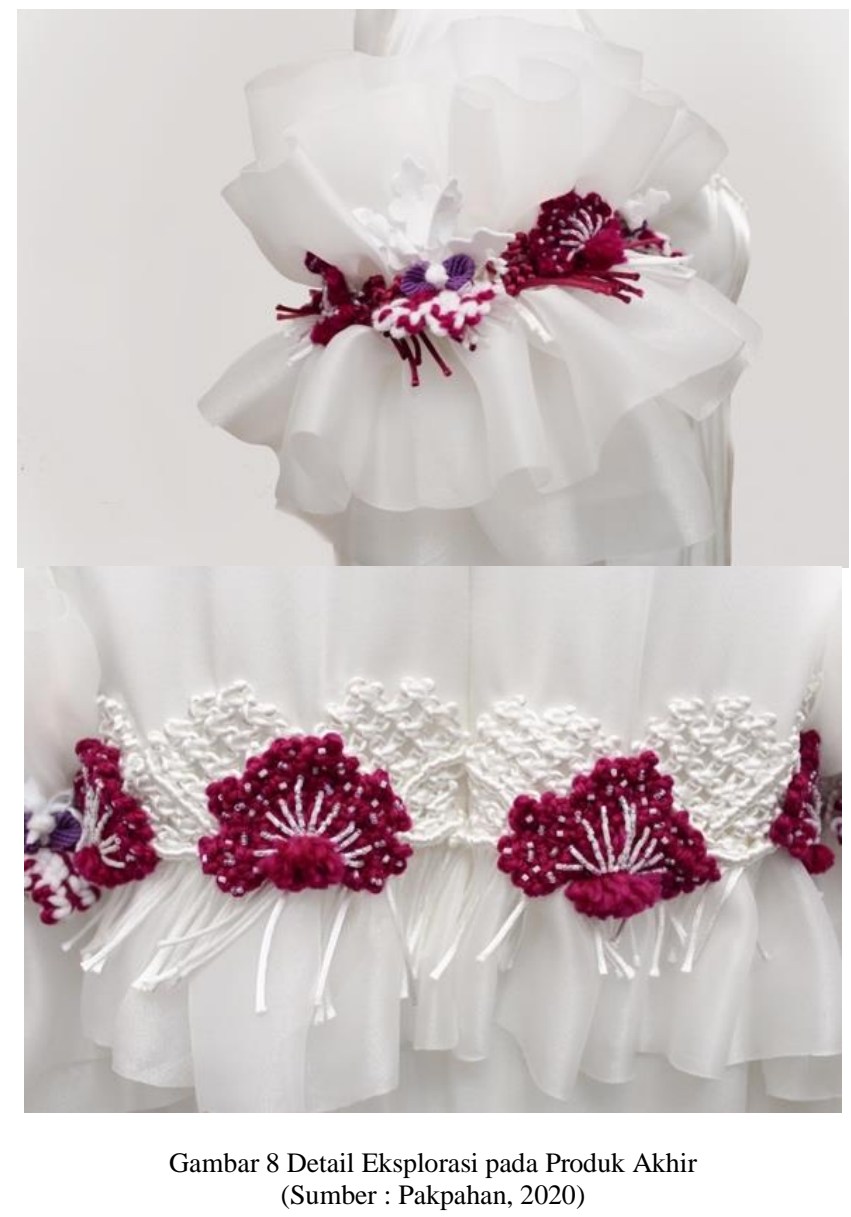

Hasil akhir busana muslim dengan elemen dekorasi makrame pada penelitian ini kemudian dianalisis dengan memerhatikan keseluruhan rupa desain dan memahami siluet busana, warna, keseimbangan, repetisi dan fokus perhatian pada busana tersebut. Gambar 9 menjelaskan poin 
analisis, secara utuh busana yang dihasilkan memiliki siluet bentuk Y dimana bagian atas terlihat lebih lebar dan mengecil pada bagian bawahnya, hal ini disebabkan oleh keberadaan cape atau sayap yang bersuar pada bagian belakang, diusung dari karakteristik kelopak bunga Anggrek yang juga bersuar. Kemudian pada bagian dasar dress memiliki bentuk tabung yang dilandaskan dari bentuk pensil karena dijahit vertikal dari pundak ke bawah rok. Adapun warna yang digunakan secara keseluruhan pada busana merupakan warna putih, hal ini sengaja dilakukan atas dasar untuk mendorong warna ungu yang berasal dari elemen dekorasi sebagai titik fokus pusat perhatian busana. Busana ini juga memiliki keseimbangan yang simetris dilihat dari kesamaan jarak dan tata letak kanan kirinya. Adapun penataan eksplorasi elemen dekoratif ditabuhkan secara repetitif pada busana.

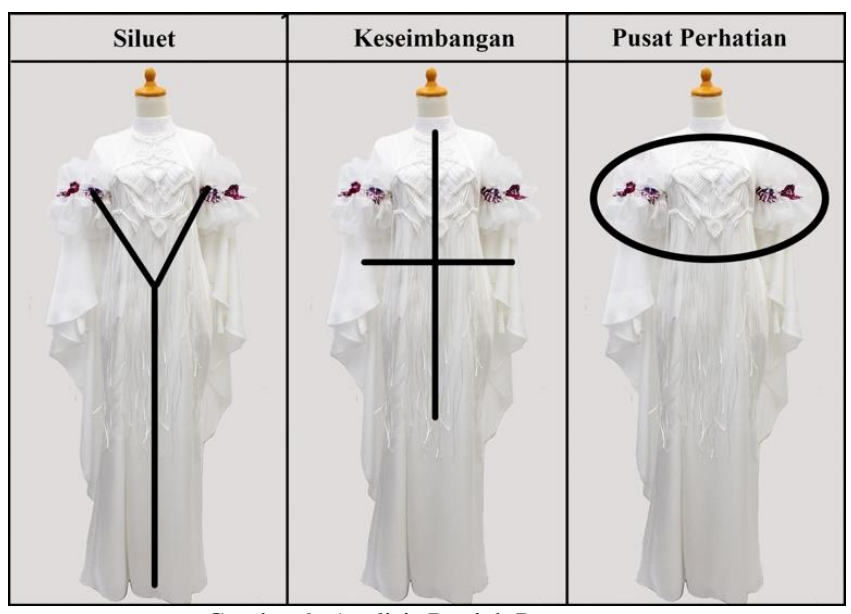

Gambar 9. Analisis Produk Perancangan

(Sumber : Pakpahan, 2020)

\section{KESIMPULAN/RINGKASAN}

Penelitian ini mengangkat keunggulan teknik makrame dengan menciptakan alternatif desain elemen dekoratif yang fokus terhadap pola struktur dan estetika yang dapat diraih oleh makrame dalam produk muslim fesyen. Berdasarkan hasil data yang diperoleh dan didukung dengan proses eksperimen yang telah dilakukan dalam penelitian ini, teknik makrame termasuk kedalam slow design atas dasar pembuatan teknik ini membutuhkan skill, keterampilan dan memerlukan biaya produksi yang tidak murah. Maka ditinjau dari hal tersebut, teknik ini sesuai apabila diaplikasikan kedalam busana pesta yang memang mengedepankan value dan tidak dibuat secara massal.

Kesesuaian penerapan makrame pada perancangan busana pesta juga dikarenakan mode yang berkembang saat ini lebih menonjolkan elemen ragam hias yang bersifat dekoratif dan makrame sendiri sangat memungkinkan untuk mencapai elemen dekoratif tersebut. Pengoptimalan teknik makrame sebagai elemen dekorasi pada busana muslim dapat ditunjang dengan penggunaan konsep, dimana pada penelitian kali ini konsep yang diusung adalah lokal konten Indonesia yaitu bunga Anggrek Pensil. Bunga Anggrek Pensil memiliki potensi sebagai inspirasi karena rupa dan fisiknya dapat dikejar dalam kombinasi variasi simpulan makrame. Memanfaatkan simpul dasar ganda dan gordin yang diaplikasikan dalam material Acrylic Wool Yarn dan Tali Satin. Menghasilkan komposisi eksplorasi yang berfungsi sebagai elemen dekoratif dengan konsep Ratu, konsisten dengan karakteristik target segmentasi, yaitu wanita berkarakteristik anggun dan feminin yang kehidupannya cenderung disorot media layaknya seorang ratu. Dengan demikian busana pesta muslim yang bersifat kekinian dengan elemen dekoratif inspirasi Anggrek Pensil yang direpsentasikan dengan makrame dapat divisualisasikan.

\section{UCAPAN TERIMA KASIH}

Penulis mengucapkan terima kasih kepada pihak-pihak yang telah membantu dalam penyusunan penelitian ini sehingga dapat terselesaikan dengan baik dan lancar.

\section{DAFTAR PUSTAKA}

[1] Kementrian Perindustrian Republik Indonesia (2012). Mimpi Indonesia : Kiblat Fashion Muslim Dunia. (https://kemenperin.go.id/ dikutip pada 4 Agustus 2020 pukul 17.02 WIB)

[2] Dewi, Mayang Tresna, Citra Puspitasari (2018). Penerapan Konsep Syar'i Modern Pada Desain Busana Pengantin Muslimah. Jurnal ATRAT.

[3] Puspitasari, Citra and Dolah, Jasni (2018). The Analysis of Integration between Hijab Concept and Fashion in Indonesia. In: The 3rd International Conference on Creative Media, Design and Technology (REKA 2018). Universitas Negeri Sebelas Maret, Surakarta, Indonesia, pp. 325-328. ISBN: 978-94-6252-612-9

[4] Sudana, I Wayan (2019) Fungsi Ornamen dalam Pengembangan Desain Fashion : Studi Kasus Ornamen Karawo di Gorontalo. Universitas Negeri Gorontalo. Gorontalo.

[5] Asriyani, Indah. (2013) Inspirasi Makrame. Surabaya. Tiara Aksa.

[6] Budiyono, dkk (2008) Kriya Tekstil, Direktorat Pembinaan Sekolah Menengah Kejuruan, Jakarta.

[7] Idrus, Muhammad (2009). Metode penelitian Ilmu Sosial. Yogyakarta: PT. Gelora Akasara Pratama.

[8] Pakpahan, Amalia Syahputri (2020). Pengembangan Desain Elemen Dekoratif Menggunakan Teknik Makrame pada Busana Pesta Muslim Dengan Inspirasi Anggrek Pensil. Telkom University.

[9] Handini, Elizabeth (2018) Penyimpanan biji dan mikropropagasi

[10] anggrek pensil (Papilionanthe hookeriana) di Kebun Raya Bogor. Pusat Konservasi Tumbuhan Kebun Raya (Kebun Raya Bogor). Lembaga Ilmu Pengetahuan Indonesia.

[11] Ernawati, Izwerni, dan Nelmira, W. (2008) : Tata Busana, Direktorat Pembinaan Sekolah Menengah Kejuruan.

[12] Ni Luh, Desi (2010) Diana Sari Terbitan: ISI. Denpasar. 